such," of course, "are not so important as is the way in which they are used " 1 ; and as the lithological term Cretaceous has come to mean something different and is now universally used for chronological purposes, so the geographical term Albian is no more " unsuitable" for chronology than for stratigraphy.

\title{
CORRESPONDENCE
}

\section{IMPRESSIONS OF BRACHIOPOD CASTS}

SIR, - In the last November-December issue of the Geological Magazine you published an article by Dr. Sisson and myself dealing with phenol formaldehyde plastic employed as a casting material in the study of internal casts of brachiopods. The technique demands the loss of the fossil and, where the matrix is a porous sandstone, the vacuum treatment which has to be adopted may lead to overmuch penetration of the rock. More recently $I$ have prepared impressions in a rubber latex (No. E I 0099, supplied at $7 s .6 d$. per half-pint by Messrs. T. Gerrard and Co., Ltd., 48 Pentonville Road, London, N. I) which gives admirable results, particularly from sandstone casts. The material is painted on to the fossil and successive layers are applied, each layer first being allowed to dry, and after about six applications a thickness is obtained sufficient to prevent distortion by curling. The rubber compound is gently prised away, the original shape of the cavities of the cast being assumed. There is no distortion; shrinkage is slow and relatively small in amount. The method appears to be much the same as that described by Fischer (Journ. Paleontology, xiii, I939, 62 I) in which a preparation of Airvulc Liquid Rubber produces a black impression. The latex mixture is creamy white in colour and Mr. Seavill and I have obtained good photographs either by using artificial light, a two and a half times filter and Eastman Panchromatic cut films, or by exposing Ilford Rapid Chromatic plates with daylight illumination without a filter.

Further impressions have been prepared in the phenol formaldehyde plastic from Upper Valentian mudstones and shales, the softness of which frequently precludes the use of any substance which has to be pulled away from the surface of the brachiopod cast.

Our procedure now is to make brachiopod impressions in the rubber latex when the specimens are preserved in sandstone

Chatwin, loc. cit., 1938, p. 53 . 
or when types or single specimens alone are available, but for casts preserved in argillaceous sediments, particularly when these are soft, the phenol formaldehyde plastic is preferred because the impression is permanent and unshrinkable.

W. F. WhitTARD.

The UNIVERSiTY,

BRISTOL.

12th March, $194^{I}$.

\section{THE UPPER OXFORD GLAY AT PURTON}

SIR,-On page I 70 of the May-June number of the Magazine the compositor has not quite accurately copicd the correlation table. In the Warboys column the broken line representing the non-scquence should have been placed about an eighth of an inch higher, so as to include some of the Bukowskii Sub-zone. In the Woodham column, beds A, B should have been shown as almost as thick as the Scarburgense Sub-zone.

BOYNe COURr,

W. J. Arkell.

BOYNDON ROAD,

Maidenhead.

gth 7 tune, 194 I.

\section{THE "DUNGHAN" LIMESTONE, AND RANIKOT BEDS IN BALUCHISTAN}

SiR,--In my last letter (I94I) I referred to collections recently made by the Burmah Oil Company on or near Dunghan Hill. The company have since sent these collections to me, and preliminary examination shows them to be of considerable stratigraphic interest.

One collection is from a section $\left(29^{\circ} 5 \mathrm{I}^{\prime}: 68^{\circ} \mathrm{I} 9^{\prime}\right)$ on the Dunghan Range, where 1,215 feet of "Dunghan Limestone" had been judged to succeed Parh Limestones and intermediate beds of Cretaceous age. I found that the first 500 feet of this "Dunghan Limestone" is of Lower to Upper Maestrichtian age, having Orbitoides media d'Archiac in its earlier levels and Omphalocyclus macropora Lamarck in its later ones. The middle of the "Dunghan Limestone" contains at least 260 feet of Upper Ranikot beds, in which Miscellanea miscella abounds. Only the uppermost 230 feet or so of this "Dunghan Limestone" is of Laki age; Alveolina globosa Leymerie, Alveolina ovoidea d'Orbigny and Sakesaria cotteri Davies being its most notable contents. This fauna resembles that of the Sakesar Limestone of the Salt Range (Davies, I937) more than the Laki of the Bolan region (Nuttall, 1925). 